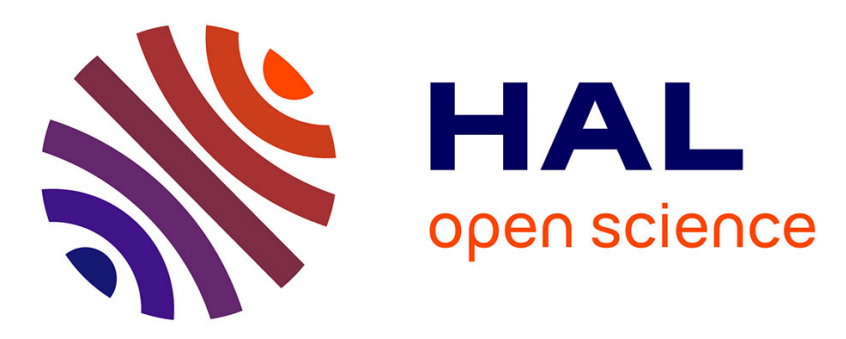

\title{
Steam reforming of methane in a synthesis gas from biomass gasification
}

\author{
H Hiblot, I Ziegler-Devin, R Fournet, Pierre-Alexandre Glaude
}

\section{To cite this version:}

H Hiblot, I Ziegler-Devin, R Fournet, Pierre-Alexandre Glaude. Steam reforming of methane in a synthesis gas from biomass gasification. International Journal of Hydrogen Energy, 2016, 41 (41), pp.18329-18338. 10.1016/j.ijhydene.2016.07.226 . hal-01349641

\section{HAL Id: hal-01349641 \\ https://hal.science/hal-01349641}

Submitted on 4 Oct 2016

HAL is a multi-disciplinary open access archive for the deposit and dissemination of scientific research documents, whether they are published or not. The documents may come from teaching and research institutions in France or abroad, or from public or private research centers.
L'archive ouverte pluridisciplinaire HAL, est destinée au dépôt et à la diffusion de documents scientifiques de niveau recherche, publiés ou non, émanant des établissements d'enseignement et de recherche français ou étrangers, des laboratoires publics ou privés. 


\title{
Steam reforming of methane in a synthesis gas from biomass
} gasification

\author{
H. Hiblot, I. Ziegler-Devin, R. Fournet, P.A. Glaude \\ Laboratoire Réactions et Génie des Procédés \\ Université de Lorraine, CNRS UMR 7274 \\ BP 20451, 1 rue Grandville, 54001 Nancy, France
}

Corresponding author:

Pierre-Alexandre Glaude

LRGP

BP 20451, 1 rue Grandville,

54001 Nancy, France

Tel : +33383175101

Fax : +33383322975

e-mail : pierre-alexandre.glaude@univ-lorraine.fr 


\section{Highlights}

- Experimental and modelling study of pyrolysis and of steam reforming of methane

- Investigation of the kinetic effect of gases issued from biomass gasification

- Steam shows little effect on $\mathrm{CH}_{4}$ conversion but allows the oxidation of products

- $\mathrm{CO}_{2}$ promotes the reaction while $\mathrm{H}_{2}$ inhibits it

- High temperature necessary to the reforming favors the formation of soot precursors 


\section{Abstract}

An experimental and modelling study of the pyrolysis and of the steam reforming of methane in mixtures representative of a gas produced from biomass gasification has been performed. The experimental study has been done in a plug flow reactor under a near atmospheric pressure (1.07 bar), for a residence time of $0.68 \mathrm{~s}$ and temperature ranging from 1200 up to $1800 \mathrm{~K}$. Reactants and products were quantified on-line at the exit of the reactor by gas chromatography. The kinetic influence of the different gases present in the synthesis gas $\left(\mathrm{H}_{2} \mathrm{O}, \mathrm{H}_{2}, \mathrm{CO}, \mathrm{CO}_{2}\right)$ on the methane conversion has been investigated. Water steam has shown a very limited impact on conversion, even at the highest temperature, while hydrogen exhibited a strong inhibiting effect on the reforming reaction. Carbon dioxide promoted slightly the reaction, unlike carbon monoxide, which had no kinetic effect. A temperature as high as $1700 \mathrm{~K}$ is necessary in these conditions to convert entirely methane. A model derived from that for the combustion of light hydrocarbons was developed with attention to the reactions of unsaturated species with hydroxyl radical $\mathrm{OH}$, which are responsible for the reforming. The main experimental trends are well reproduced. Carbon reforming occurs mainly by reactions of $\mathrm{OH}$ radical with unsaturated $\mathrm{C}_{2}$ molecules, which are soot precursors. Process conditions necessary for high temperature methane reforming would then be favorable to undesirable soot formation.

Keywords: Steam reforming, pyrolysis, methane, syngas, kinetic modeling 


\section{Introduction}

Environmental concerns, especially greenhouse gases emissions, have led to an increased interest in the use of renewable energies. Biomass is widely used in combustion but can also be involved in more advanced applications such as the production of liquid combustibles (GTL) or the cogeneration by means of a fuel cell [1]. These applications require the production of a high quality synthesis gas (syngas, mixture of $\mathrm{CO}$ and $\mathrm{H}_{2}$ ). Cellulosic biomass may be a promising feedstock through the gasification processes [2,3]. Wood gasification is a heterogeneous process between a carboncontaining solid and an oxidizer such as $\mathrm{O}_{2}, \mathrm{CO}_{2}$ or water steam [4,5]. The main products are $\mathrm{CO}$ and $\mathrm{H}_{2}$, but large fractions of hydrocarbons, char and soot, which are undesirable to achieve a high efficiency and avoid fouling, are yielded too. Three phases can be distinguished [6]. The solid phase includes soot and char. The liquid phase involves the condensable intermediates named as tars, while carbon oxides, hydrogen, water, methane and other light hydrocarbons remain in the gas phase. The hot gases from the gasification need to be cleaned drastically to reach the severe specifications of fuel cells or catalytic processes [7]. Catalytic post treatment are usually used to clean the gases at the exhaust of the gasification [8], but the severe conditions, especially the high temperature, lead to a short life time for the catalytic bed. An non catalytic alternative can be a high temperature steam gasification and reforming of a mixture of biomass and methane, which permits to optimize hydrogen yields for downstream liquid fuel synthesis and shows a rather good efficiency over autothermal process $[9,10]$. Another alternative process would be a homogeneous high temperature reforming of tars $(\mathrm{T}>1273 \mathrm{~K})$ and light hydrocarbons at the exhaust of the gasifier. This would allow a cleaning of the gas and an improvement of the global yield by oxidizing the remaining hydrocarbons into $\mathrm{CO}$ and $\mathrm{H}_{2}$ [11]. The technical evaluation of such an alternative is required to know precisely 
the kinetics of the hydro reforming of hydrocarbons. These reactions are also involved in other processes proposed for the production of hydrogen, such as solar driven methane [12] or carbonaceous material steam reforming $[13,14]$ or auto-thermal reforming using partial oxidation of hydrocarbons [15-18]. Up to now, modeling of gas phase reforming or water gas shift reaction in thermal processes often relies on thermochemical equilibrium [19] or global stoichiometric equations [20].

Few studies have been devoted to the reaction of hydrocarbons and tars with water steam. Jönsson [21] studied the conversion of methane in a gas obtained from wood pyrolysis, in a tubular reactor. The conversion was found to be maximum at $1523 \mathrm{~K}(60 \%$ conversion) and to be not very sensitive to the amounts of water and oxygen, while hydrogen showed an inhibiting effect. Tijmensen [22] studied the reaction of methane with water between 973 and $1373 \mathrm{~K}$ between 10 and 35 bar and proposed a global reaction rate. Valin et al. [23] followed the conversion of methane in a pilot scale tubular reactor in a gas mixture representative of that obtained after the gasification of wood. $90 \%$ of the hydrocarbon was oxidized at $1653 \mathrm{~K}$ for a residence time of $2 \mathrm{~s}$ and they noted also the inhibiting effect of hydrogen [24].

Reactions of tars have been also the subject of some studies. At high temperature, tars are mostly composed of aromatic and polyaromatic compounds [6]. The major components are benzene, toluene, indene, naphthalene, and phenol [25]. These compounds could then be used as surrogates for the reactions of tars. Jess [26] studied the steam reforming of benzene, toluene, and naphthalene in a tubular reactor between $973 \mathrm{~K}$ and $1673 \mathrm{~K}$ under 1,6 bar. Toluene was found to be completely consumed at $1300 \mathrm{~K}$ while a temperature of $1700 \mathrm{~K}$ was necessary to convert benzene.

Although many detailed kinetic models exist for the thermal decomposition and the combustion of light hydrocarbons, especially for methane [27-37], these models were not 
designed to simulate the slow oxidation by water in a reducing atmosphere containing mainly $\mathrm{CO}$ and $\mathrm{H}_{2}$. Reactions at very high temperature in a mixture rich in $\mathrm{H}_{2} \mathrm{O}, \mathrm{CO}, \mathrm{CO}_{2}$ and $\mathrm{H}_{2}$ need further investigations. The present work aimed to go further than the process study by Valin et al. [23] and to investigate the kinetic behavior and interactions of the different compounds in well-defined conditions. An experimental and modelling study of the thermal cracking of methane has been performed at high temperature in a synthetic gas representative of that produced by the gasification of biomass. The effect of temperature and composition has been investigated and is discussed.

\section{Experiments}

The experimental study has been performed in a continuous flow reactor under a near atmospheric pressure (800 Torr, 1.07 bar). The reactor was a tubular mullite pipe (60 cm length and $2.4 \mathrm{~cm}$ internal diameter) of internal volume $271 \mathrm{~cm}^{3}$ involving a S/V ratio of $1.67 \mathrm{~cm}^{-1}$. The mullite, which is an oxide of silicon and aluminum, allows a heating up to 1900 K. Comparisons were made at lower temperature, between 973 and 1273 K, with a fused silica reactor to check that no wall reaction occurs. Results were found identical in the case of the pyrolysis of ethane up to $1273 \mathrm{~K}$. As pyrolytic carbon deposits were formed in the hottest part of the reactor, the effect of reactor aging was checked in another set of experiments. For a fixed temperature, thermal decomposition of methane, ethylene and acetylene was performed in neat and in coked reactors. It appeared that the formation of carbon deposit had a little promoting influence on the consumption of acetylene, without affecting the conversion of methane and other $\mathrm{C}_{2}$ hydrocarbons. Experiments were then performed in all cases in clean reactors. A horizontal Vecstar oven allowed heating the reactor up to $1870 \mathrm{~K}$. Temperature profiles were measured by a type $\mathrm{S}$ thermocouple coated in an alumina pipe. Uncertainty is estimated to $\pm 20 \mathrm{~K}$. Figure 1 presents 
temperature profiles. A plateau of $16 \mathrm{~cm}$ length was reached at the set point temperature but lower temperature regions cannot be neglected in modeling. The reactor can be considered as a plug flow reactor in the studied conditions between $1000 \mathrm{~K}$ and $1800 \mathrm{~K}$. For a residence time of $0.68 \mathrm{~s}$ calculated in the $16 \mathrm{~cm}$ long hot section of the reactor, the Péclet number lies between 120 and 140 as a function of the temperature, whereas a value above 50 allows to consider the reactor as a plug flow reactor.

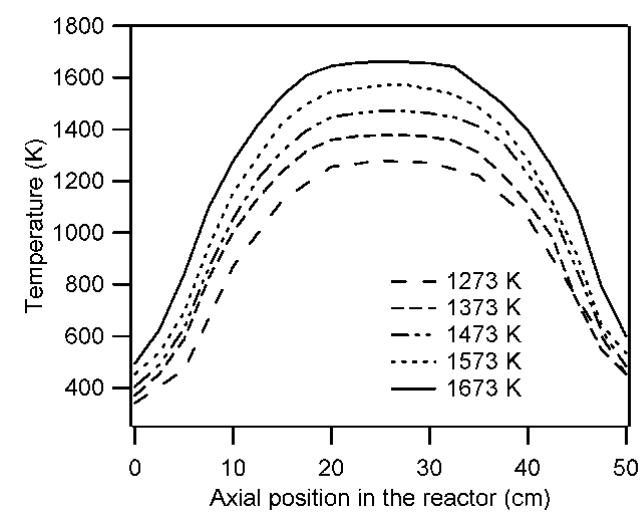

Figure 1: Temperature profiles in the reactor as a function of the oven set point.

Messer and Air Liquide supplied gases, with a purity at least above $99.9 \%$. Water was added through a Bronkhorst liquid mass flow controller coupled with a controlled evaporator mixer from the same supplier. For all the experiments, residence time was fixed to $0.68 \mathrm{~s}$ (in the hot area), pressure was 800 Torr (1,07 bar) and argon was used as diluent in order to make negligible the thermal effect and the volumetric expansion of the flow due to the reaction.

On-line analyses were done by gas chromatography. Permanent gases were quantified by a thermal conductivity detector (TCD) and hydrocarbons by a flame ionization detector (FID). Light species, i.e. $\mathrm{H}_{2}, \mathrm{CO}, \mathrm{CO}_{2}$, methane, ethane, ethylene and acetylene were separated with a Carbosphere packed column. The uncertainties are 
around 5\%; the detection threshold is below $1 \mathrm{ppm}$ with FID, it is 30 and $10 \mathrm{ppm}$ for hydrogen and carbon oxides with TCD, respectively. Heavier compounds up to $\mathrm{C}_{4}$ were separated with a Hayesep $D$ packed column. When $C_{2}$ were added in the reacting mixture to test the kinetic effect of the coking of the walls, propene, allene (propadiene), propyne, 1-butene, 1,3-butadiene, vinylacetylene and diacetylene could be detected (not presented here).

\section{Modeling}

A detailed kinetic mechanism has been developed in order to simulate and analyze the experimental results of steam reforming. It was based on a model for the combustion of $\mathrm{C}_{0}-\mathrm{C}_{2}$ species, which includes also a reaction base for the reaction of $\mathrm{C}_{3}-\mathrm{C}_{5}$ unsaturated hydrocarbons validated in flame and shock tube conditions $[38,39]$. The $\mathrm{C}_{0^{-}}$ $\mathrm{C}_{2}$ reaction base contains all unimolecular and bimolecular reactions between species involving less than three carbon atoms and was especially validated against experimental results for the combustion of methane and ethane. Pressure dependence is taken into account for reaction of light species when data are available in the literature.

In the mechanism, reactions involving $\mathrm{HO}_{2}, \mathrm{H}_{2} \mathrm{O}_{2}$ and $\mathrm{O}_{2}$ were negligible and were removed since molecular oxygen was not present. The enthalpy of reaction of the hydroxyl radical, which is the main species responsible for steam reforming, was updated according to Burcat and Ruscic [40]. Several kinetic parameters were updated in order to include recent recommended values for the sensitive reactions. Data from the review by Baulch et al [41] were used for the $\mathrm{H}$-abstraction by a $\mathrm{H}$-atom and $\mathrm{OH}$ radical on methane, by $\mathrm{H}$-atom on methyl radical producing $\mathrm{H}_{2}$ and $\mathrm{CH}_{2}$ diradical or the decomposition of vinyl radical to ethylene and $\mathrm{H}$-atom. Special care was given to reactions of methyl radical and unsaturated species with $\mathrm{H}_{2} \mathrm{O}$ and $\mathrm{OH}$ radical, which can be involved in the reforming 
process. Combination of methyl and hydroxyl radical yields numerous products: methanol if the adduct is stabilized [41], or decomposition products such as water and $\mathrm{CH}_{2}$ diradical [42], formaldehyde and $\mathrm{H}_{2}$ [43], or methoxy radical and $\mathrm{H}$-atom. Important reactions in the reforming of hydrocarbons are the addition of $\mathrm{OH}$ radical on unsaturated hydrocarbons, yielding the first $\mathrm{C}-\mathrm{O}$ bonds that lead ultimately to the production of $\mathrm{CO}$. These reactions are usually not sensitive in combustion and both rate constants and products are subject to discussion. In the case of the reactions $\mathrm{OH}+\mathrm{C}_{2} \mathrm{H}_{4}$ and $\mathrm{OH}+\mathrm{C}_{2} \mathrm{H}_{2}$, two pathways are possible: the $\mathrm{H}$-atom abstraction and the formation of an adduct, which decomposes. In the case of ethylene, the adduct can decompose through three routes producing $\mathrm{CH}_{3}$ and $\mathrm{HCHO}, \mathrm{CH}_{2} \mathrm{CHOH}$ and an $\mathrm{H}$-atom, and $\mathrm{CH}_{3} \mathrm{CHO}$ and an $\mathrm{H}$-atom, respectively [41]. The formation of methyl radical and formaldehyde is dominant and the concurrent routes have been neglected. According to the literature, the rate parameters of the $\mathrm{H}$-abstraction and of the addition were supposed to be similar $\left(\mathrm{k}=10^{13} \mathrm{exp}\right.$ ($5940 \mathrm{cal} \mathrm{mol}^{-1} / \mathrm{RT}$ ) $\mathrm{cm}^{3} \mathrm{~mol}^{-1} \mathrm{~s}^{-1}$ ), and their sum equal to the value proposed for the global reaction of $\mathrm{OH}$ with ethylene [41]. These choices led to average values in comparison to studies of the literature. In the case of reactions between $\mathrm{OH}$ and acetylene, the data for the $\mathrm{H}$-abstraction was taken from Tsang and Hampson [44]. The addition was supposed to produce mainly ketene $\left(\mathrm{CH}_{2} \mathrm{CO}\right)$ and an $\mathrm{H}$-atom with a rate constant of $1.1 \times 10^{13} \mathrm{exp}$ ($\left.7174 \mathrm{cal} \mathrm{mol}^{-1 / R T}\right) \mathrm{cm}^{3} \mathrm{~mol}^{-1} \mathrm{~s}^{-1}$ [45]. Carbon dioxide has shown a promoting effect on the steam reforming of hydrocarbons. By analogy with reaction of $\mathrm{CH}_{3}\left(\right.$ and $\left.\mathrm{C}_{2} \mathrm{H}_{5}\right)$ with $\mathrm{CO}_{2}$, yielding $\mathrm{CO}$ and $\mathrm{CH}_{3} \mathrm{O}$ (or $\mathrm{C}_{2} \mathrm{H}_{5} \mathrm{O}$, respectively) [46], reactions of $\mathrm{C}_{2} \mathrm{H}_{3}$ and $\mathrm{C}_{2} \mathrm{H}$ radical with $\mathrm{CO}_{2}$ were added:

$$
\begin{aligned}
& \mathrm{C}_{2} \mathrm{H}_{3}+\mathrm{CO}_{2} \rightarrow \mathrm{CH}_{2} \mathrm{CHO}+\mathrm{CO} \\
& \mathrm{C}_{2} \mathrm{H}+\mathrm{CO}_{2} \rightarrow \mathrm{HCCO}+\mathrm{CO}
\end{aligned}
$$


The pre-exponential factors were estimated to $10^{13} \mathrm{~cm}^{3} \mathrm{~mol}^{-1} \mathrm{~s}^{-1}$, as in the case of the addition of a radical on a double bond [47]. The activation energies were estimated from an Evans-Polanyi plot made with the reference reactions of methyl and ethyl radicals [46], which led to activation energies of $17 \mathrm{kcal} \mathrm{mol}^{-1}$ and $0 \mathrm{kcal} \mathrm{mol}^{-1}$, respectively.

Simulations were performed with the CHEMKIN suite [48]. The plug flow reactor was modeled as a cascade of small continuously stirred reactors taking into account the experimental temperature profile.

\section{Results and Discussion}

\subsection{Influence of water steam on methane pyrolysis}

The degradation of pure methane has been studied as a function of temperature with and without the addition of water (i.e. pyrolysis condition). The initial fractions of methane and water were $0.63 \%$ and $4.8 \%$, respectively, diluted in argon. The profiles of methane and of the main products are presented in figure 2 in the pyrolysis and the case of the addition of water. An interesting result is that the reactivity of methane is not very sensitive to the addition of water. Its consumption starts around $1400 \mathrm{~K}$ in these conditions and the conversion is total around $1700 \mathrm{~K}$ with and without water. Both experiments and modeling show that water slightly promotes the reaction below $1523 \mathrm{~K}$ but inhibits it above this temperature. Conversely, the addition of water changes dramatically the product distribution: while the pyrolysis leads to large amounts of $\mathrm{C}_{2}$, especially acetylene, solid carbon and soot, the steam reforming produces $\mathrm{H}_{2}, \mathrm{CO}$ and $\mathrm{CO}_{2}$ as major products, but also small amounts of $\mathrm{C}_{2}$. Ethylene reaches a maximum of about $60 \mathrm{ppm}(\mathrm{mol})$ at $1423 \mathrm{~K}$ (150 ppm in pyrolysis at the same temperature), and acetylene an amount of about 550 ppm (mol) at $1523 \mathrm{~K}$ (to compare with a maximum of $2000 \mathrm{ppm}$ at $1500 \mathrm{~K}$ in pyrolysis). 
The model reproduces fairly well the profiles and the influence of temperature in pyrolysis and in presence of steam. The fraction of final products, i.e. hydrogen and carbon oxides, are well simulated. In pyrolysis, the model tends to overestimate acetylene at the highest temperatures, above $1573 \mathrm{~K}$. The formation of solid carbon at the reactor wall and of soot becomes important in pyrolysis at these temperatures, whereas the gas phase model does not take into account these heterogeneous reactions. Studies on the carbon vapor deposition have shown that acetylene is one of the main precursor of pyrolytic carbon. A rate constant for the global reaction of deposition

$$
\mathrm{C}_{2} \mathrm{H}_{2} \rightarrow 2 \mathrm{C}_{(\mathrm{S})}+\mathrm{H}_{2}
$$

was determined in the case of carbon vapor infiltration during propane pyrolysis [49]. The same reaction has been tested in the present mechanism. The pre-exponential factor has been corrected to take into account the change of the surface/volume ratio between both reactors, and multiplied by a factor 2 , within the range of uncertainty. The rate constant equals finally $1.6 \times 10^{5} \exp \left(-40000 \mathrm{cal} \mathrm{mol}^{-1 / R T}\right) \mathrm{s}^{-1}$. Hydrogen, ethylene and acetylene profiles obtained in pyrolysis with this modified mechanism are shown in Figure 2 (dotted lines). The heterogeneous reaction allows to reproduce perfectly the experimental profile of hydrogen above $1600 \mathrm{~K}$. The most dramatic effect can be seen on acetylene fraction. Instead of an increase of the concentration to a plateau, acetylene profile reaches a maximum, as observed experimentally, and decreases at high temperature to produce solid carbon. Even if the temperature of the maximum is slightly shifted toward high temperature compared to the experiments, it is important to note that the heterogeneous reaction, determined in another reactor during propane pyrolysis, permits to reproduce the present data without further adjustment. The effect is rather moderate on ethylene profile, even if a better fit of the experimental data is obtained at the highest temperatures. 
No effect was found on other species, methane and hydrogen and the reaction was found completely negligible in the case of steam reforming.

The low sensitivity of water on the global reactivity is explained by the low reactivity of water: the initial reaction channels consuming methane remains similar in both cases, i.e. a $\mathrm{H}$-abstraction by a $\mathrm{H}$-atom (or an $\mathrm{OH}$ radical when water is added) producing a methyl radical which is not very reactive and leads to bimolecular reactions. Water does not allow a new promoting route even at the highest temperatures. The slight promoting effect of water below $1523 \mathrm{~K}$ is due first to the reaction of $\mathrm{H}$-atoms with water to produce $\mathrm{H}_{2}$ and $\mathrm{OH}$ radicals. These latter react faster by $\mathrm{H}$-atom abstraction with methane than $\mathrm{H}$ atoms. To a lesser extent, methyl radical reacts with $\mathrm{H}_{2} \mathrm{O}$ to produce an $\mathrm{H}$-atom and methanol. This latter molecule, much more reactive than methane, acts somewhat as a degenerate branching agent in unimolecular decompositions, which produce new radicals. When the temperature increases, $\mathrm{OH}$ radical reacts more with acetylene to yield an $\mathrm{H}$-atom and ketene. The latter react by addition with an $\mathrm{H}$-atom to form $\mathrm{CH}_{3} \mathrm{CO}$ that decompose immediately into $\mathrm{CO}$ and a methyl radical. The scheme consists then in replacing an $\mathrm{OH}$ radical by a methyl radical, much of which yielding back methane by termination with an $\mathrm{H}$-atom. Furthermore, the highest amount of $\mathrm{H}_{2}$ in pyrolysis at high temperature inhibits methane conversion, as discussed below. 

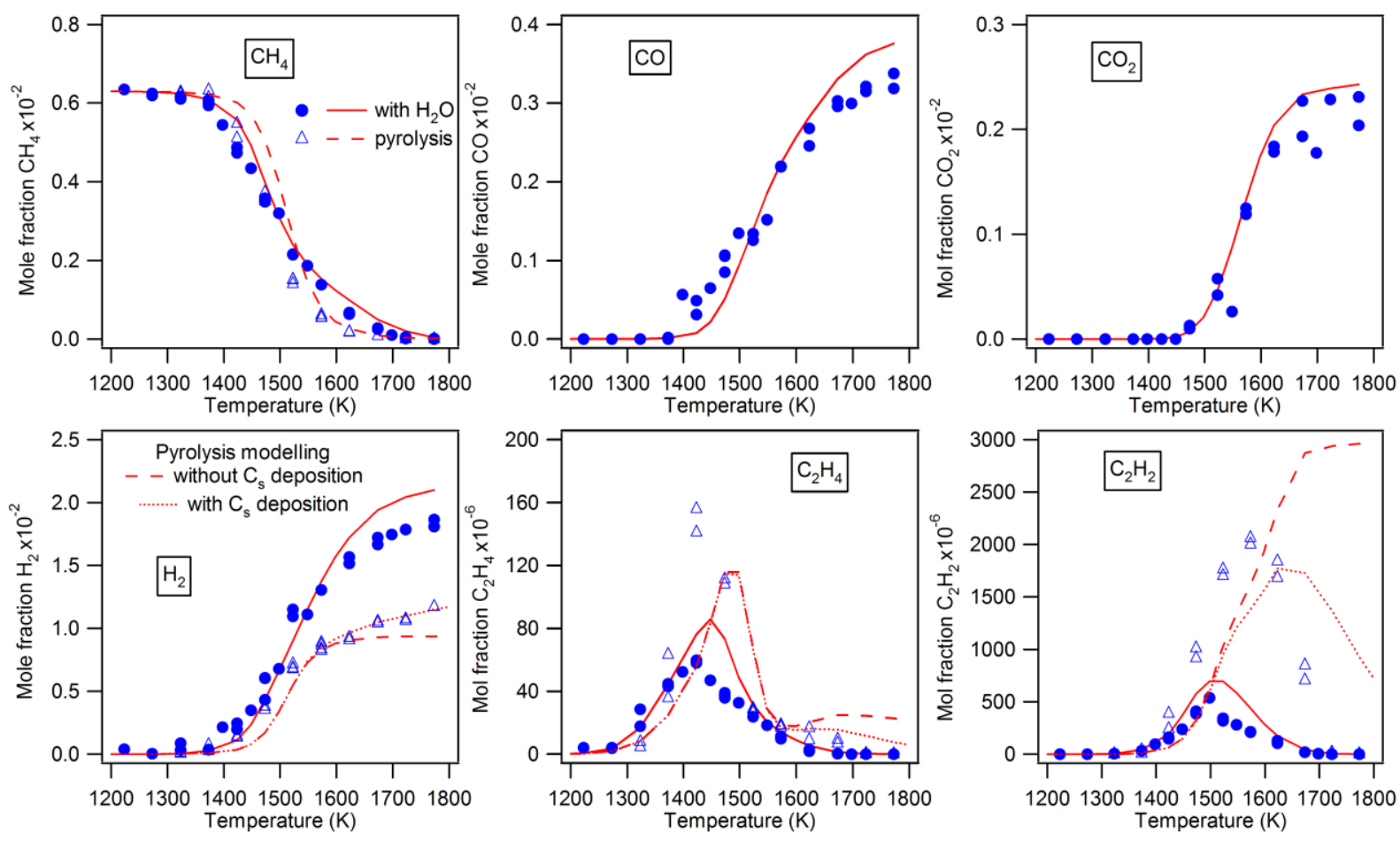

Figure 2: Profiles of species during the steam reforming of methane. In the cases of methane, $\mathrm{H}_{2}$, and $\mathrm{C}_{2}$, experimental results in pyrolysis condition without water are also displayed. $\mathrm{X}_{\mathrm{CH} 4}=0.63 \%, \mathrm{X}_{\mathrm{H} 2 \mathrm{O}}=4.8 \%$, diluent argon. Residence time is $0.68 \mathrm{~s}$. Points represent experimental results and lines simulations. Dash lines refer to the pyrolysis simulation, dotted lines to the simulation including a reaction of formation of solid carbon.

\subsection{Influence of $\mathrm{H}_{2}$ on methane pyrolysis}

The influence of hydrogen in reactants $(0-11 \%)$ has been investigated during the pyrolysis of neat methane. Figure 3 displays the amount of methane as a function of the fraction of hydrogen added for two temperatures. At $1523 \mathrm{~K}$, a strong inhibiting effect appears even for amounts of hydrogen as low as $1 \%$. When amounts larger than $10 \%$ are added, the conversion of methane is close to be stopped. The fractions of hydrogen and of $\mathrm{C}_{2}$ products at the outlet of the reactor at $1523 \mathrm{~K}$ are plotted in Figure 4 as a function of $\mathrm{H}_{2}$ at the inlet of the reactor. A large decrease of the amount of acetylene is observed in both experiments and simulations when hydrogen is added. Conversely, fractions of ethylene and ethane remain almost constant when hydrogen is added. The 
model reproduces very well the amount of $\mathrm{H}_{2}$ produced in addition to that present as reactant. As maximum mole fraction reached by $\mathrm{C}_{2}$ species are slightly shifted toward higher temperatures (Figure 1), ethylene and acetylene amounts are somewhat overestimated for the lowest additions of hydrogen in figure 4 . This is due to the significant uncertainties on reactions of consumption of acetylene with water and $\mathrm{OH}$ at high temperatures, but trends are however well predicted. At $1673 \mathrm{~K}, \mathrm{H}_{2}$ keeps an inhibiting effect, but less dramatic (Figure 3): while the conversion of pure methane is close to 99\%, the addition of $11 \%$ of hydrogen makes it drop to around $70 \%$. Whatever the temperature, the model reproduces very well the experimental observations. Reactions of methyl radicals explain the strong inhibiting effect of $\mathrm{H}_{2}$. In thermal decomposition, methane yields methyl radicals by initiation (reaction 1 ) or by $\mathrm{H}$-atom abstraction by another $\mathrm{H}$ atom (reaction 2). $\mathrm{CH}_{3}$ combines with itself to produce $\mathrm{C}_{2}$ (reaction 3 and 4 ), or reacts in the reverse reactions with $\mathrm{H}$ or $\mathrm{H}_{2}$ to yield methane. The addition of $\mathrm{H}_{2}$ in pyrolysis favors these latter and strongly limit the formation of $\mathrm{C}_{2}$ and subsequent products.

$$
\begin{aligned}
& \mathrm{CH}_{4}(+\mathrm{M}) \leftrightarrows \mathrm{CH}_{3}+\mathrm{H}(+\mathrm{M}) \\
& \mathrm{CH}_{4}+\mathrm{H} \leftrightarrows \mathrm{CH}_{3}+\mathrm{H}_{2} \\
& \mathrm{CH}_{3}+\mathrm{CH}_{3}(+\mathrm{M}) \rightarrow \mathrm{C}_{2} \mathrm{H}_{6}(+\mathrm{M}) \\
& \rightarrow \mathrm{C}_{2} \mathrm{H}_{5}+\mathrm{H}(+\mathrm{M})
\end{aligned}
$$

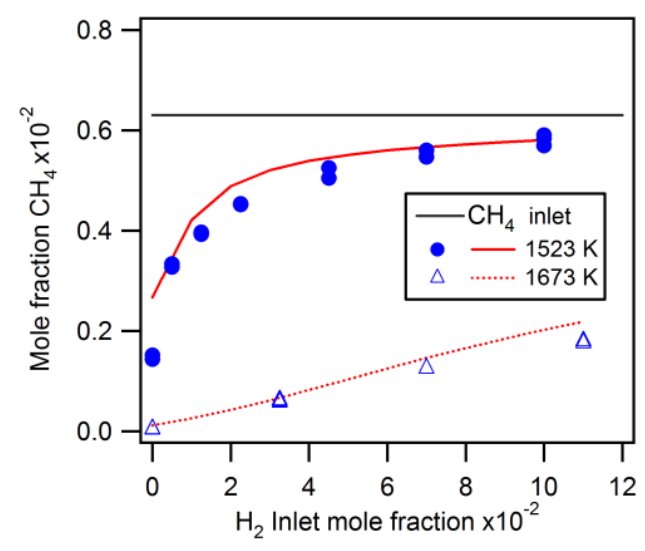

Figure 3: Profiles of methane during its pyrolysis as a function of the fraction of $\mathrm{H}_{2}$ at $1523 \mathrm{~K}$ and $1673 \mathrm{~K}$. Residence time is $0.68 \mathrm{~s}$. Points represent experimental results and line simulations. The horizontal line gives the initial mole fraction of methane. 


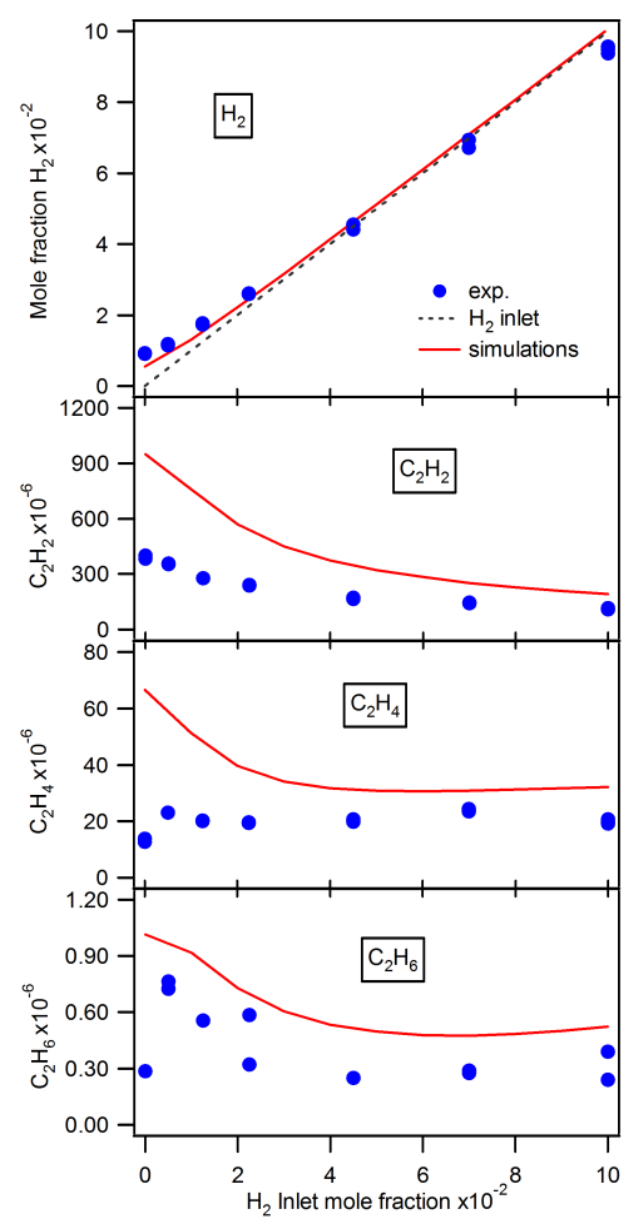

Figure 4: Profiles of hydrogen and products during methane pyrolysis as a function of the fraction of $\mathrm{H}_{2}$ at $1523 \mathrm{~K}$. Residence time is $0.68 \mathrm{~s}$. Points represent experimental results and line simulations.

\subsection{Influence of carbon oxides on methane pyrolysis}

A possible kinetic effect of the addition of carbon oxides on the thermal reaction of methane has been also investigated. Carbon monoxide and dioxide are contained in large amounts in gas from biomass or coal gasification. An increasing mole fraction of $\mathrm{CO}$ was added to $0.63 \%$ of methane, up to $7 \%$ at 1523 and up to $10 \%$ at $1673 \mathrm{~K}$ (Figure 5). Whatever the temperature and the fraction of additive, no change can be observed in methane conversion, which reaches $75 \%$ at $1523 \mathrm{~K}$ and $99.3 \%$ at $1673 \mathrm{~K}(60 \%$ and $98 \%$ by simulation, respectively). The amount of reaction products; i.e. hydrogen, ethylene, 
and acetylene remains also constant at both temperatures whatever the fraction of $\mathrm{CO}$, as illustrated in Figure 5 in the case of hydrogen.

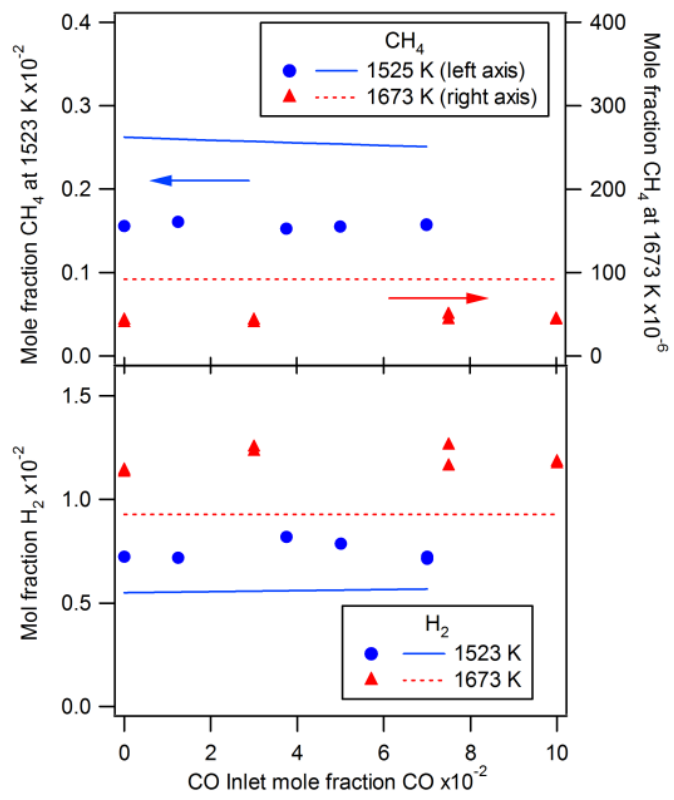

Figure 5: Profiles of methane and hydrogen during methane pyrolysis as a function of the fraction of added $\mathrm{CO}$ at $1523 \mathrm{~K}$ and $1673 \mathrm{~K}$. Residence time is $0.68 \mathrm{~s}$. Points represent experimental results and line simulations.

Contrariwise, $\mathrm{CO}_{2}$ addition shows a promoting effect on the reactivity, as displayed in Figure 6. At $1523 \mathrm{~K}$, neat methane conversion in pyrolysis reaches $78 \%$ experimentally. The conversion increases up to $97 \%$ for a $10 \%$ mole fraction of carbon dioxide in the reactive mixture. Simultaneously, $\mathrm{CO}_{2}$ is slightly consumed (experimental points are below the fraction at the reactor inlet in figure 6) and $\mathrm{CO}$ appears among the reaction products. The amount of hydrogen and $\mathrm{C}_{2}$ decreases, as can be seen in the bottom of Figure 6. The model reproduces well the trends, considering the slight underprediction of neat methane conversion at $1523 \mathrm{~K}$. In these blends, $\mathrm{CO}_{2}$ acts as an oxidizer through the reaction $\mathrm{CO}_{2}+\mathrm{H} \leftrightarrows \mathrm{CO}+\mathrm{OH}$. The hydroxyl radicals react hereafter with methane or $\mathrm{H}_{2}$, reducing the inhibiting influence of this latter. They also can add on unsaturated $\mathrm{C}_{2}$ to produce oxygenated compound, such as formaldehyde, which decomposes quickly at 
this high temperature. Note that the direct reaction between $\mathrm{CO}_{2}$ and methyl radical to produce $\mathrm{CO}$ and methoxy radical, included in the model, remains negligible.

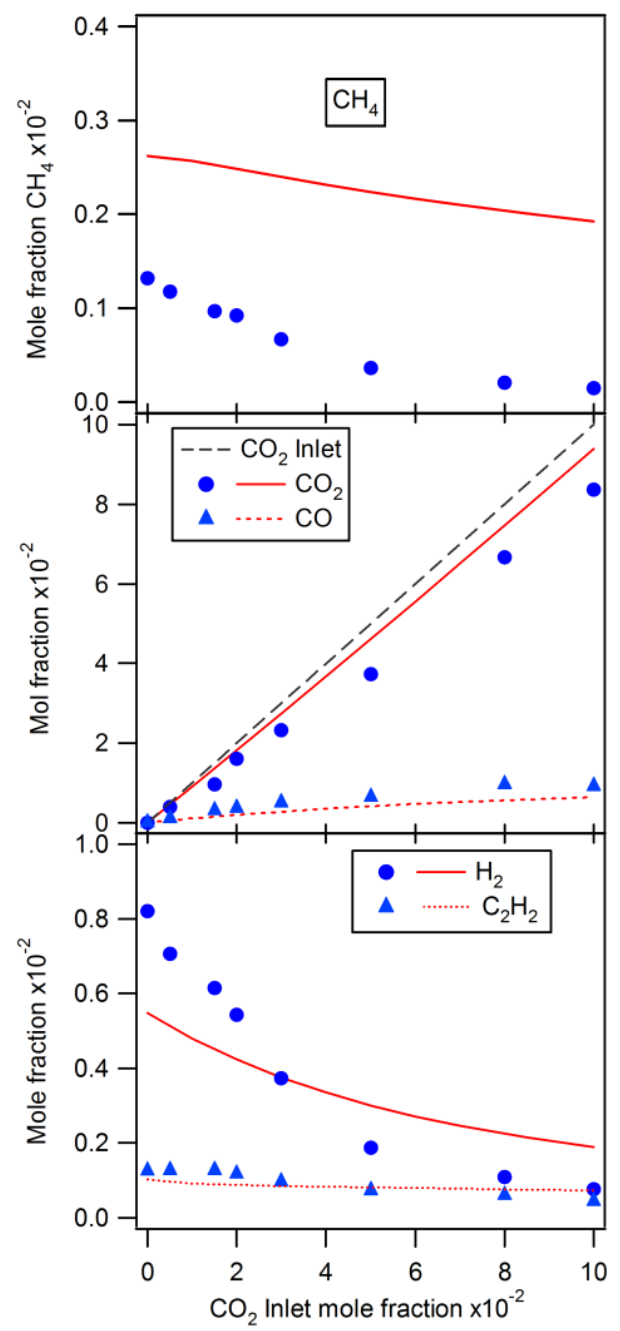

Figure 6: Profiles of methane, $\mathrm{CO}_{2}$ and products during methane pyrolysis as a function of the fraction of added $\mathrm{CO}_{2}$ at $1523 \mathrm{~K}$. Residence time is $0.68 \mathrm{~s}$. Points represent experimental results and line simulations.

\subsection{Methane reforming in complex mixtures}

The reaction of a mixture representative of a gas issued from biomass gasification has also been investigated as a function of the temperature. The blend contained methane (1.26\%), $\mathrm{CO}(5 \%), \mathrm{H}_{2}(5 \%)$, and $\mathrm{H}_{2} \mathrm{O}(5 \%)$ diluted in argon. Results are presented in figure 7. It appears that the reactivity of the hydrocarbon is lower than in the case of the steam reforming presented in figure 2 . The inhibiting effect of hydrogen shifts the reaction 
towards higher temperatures. Methane consumption starts around $1423 \mathrm{~K}(1400 \mathrm{~K}$ for pure methane) and a temperature higher than $1723 \mathrm{~K}$ is necessary to reform completely the hydrocarbon. $\mathrm{H}_{2}$ and carbon oxides are the major products. $\mathrm{CO}$ mole fraction exhibits a $\mathrm{V}$ shape profile: it is converted to $\mathrm{CO}_{2}$ at intermediate temperature by $\mathrm{OH}$ radical but at higher temperature, the reverse reduction of $\mathrm{CO}_{2}$ by $\mathrm{H}$-atom and the reforming of methane to $\mathrm{CO}$ make its production predominant. The production of $\mathrm{CO}_{2}$ is only due to the reaction of $\mathrm{CO}$ with $\mathrm{OH}$ radicals, which rate constant is well-known. The correct simulation of the amount of $\mathrm{CO}_{2}$ indicates that the amount of $\mathrm{OH}$ radicals is correctly predicted by the model. Ethylene and acetylene are produced in important amounts at intermediate temperatures. Note that if methane concentration is twice that used in the study of the reforming of pure methane, the amount of acetylene reaches a maximum as high as $3500 \mathrm{ppm}$ against 550 in the first conditions. This explains the significant formation of soot and carbon deposit that was observed experimentally. The model reproduces well both reactivity and product distribution, the simulation of the amounts of $\mathrm{C}_{2}$ compounds is somewhat underestimated. 

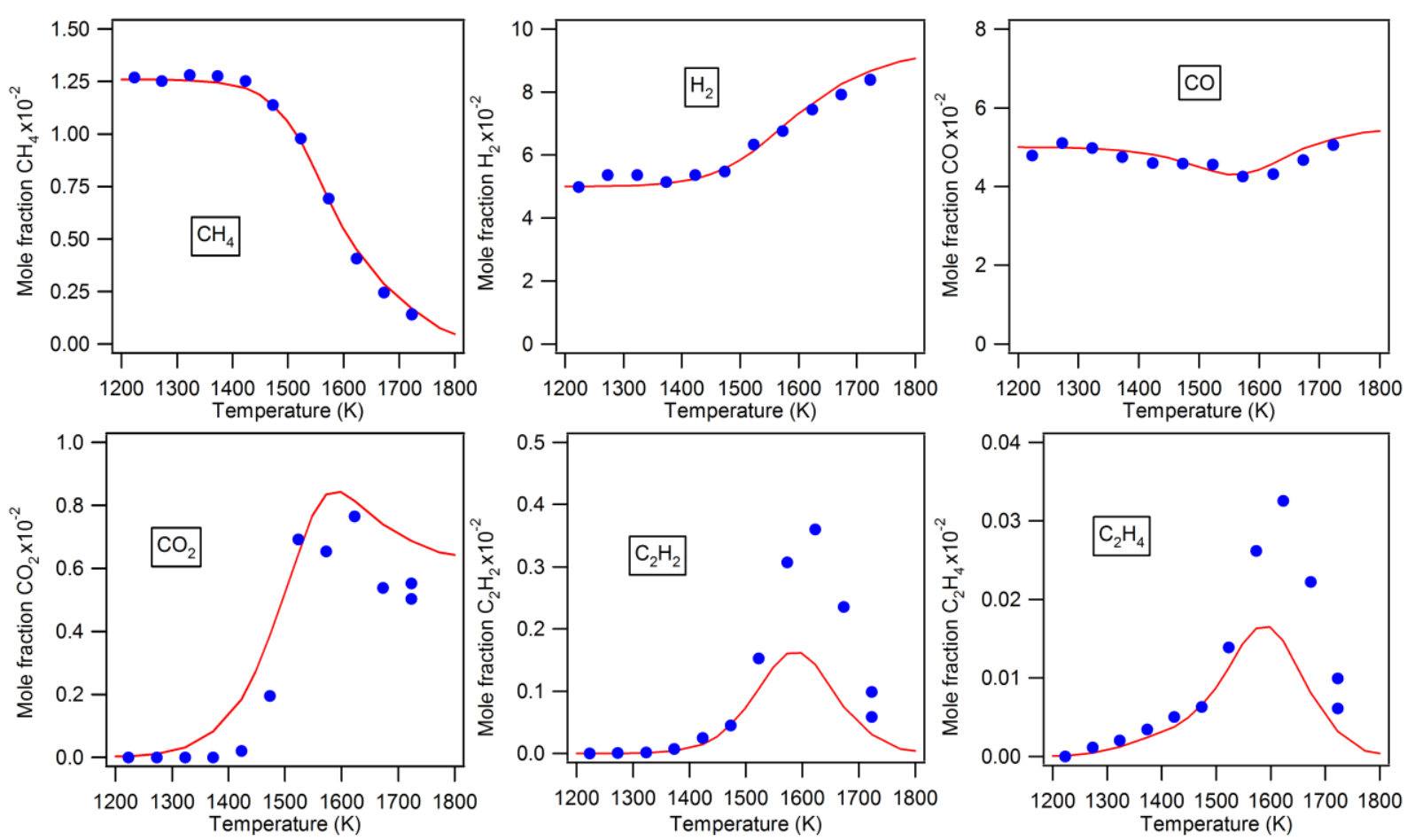

Figure 7: Profiles of species during the reaction of a mixture methane (1.26\%), CO $(5 \%), \mathrm{H}_{2}(5 \%), \mathrm{H}_{2} \mathrm{O}(5 \%)$ as a function of temperature. Residence time is $0.68 \mathrm{~s}$. Points represent experimental results and line simulations.

A second mixture representative of a gas issued from biomass gasification has been investigated by replacing carbon monoxide by carbon dioxide. The mixture contained methane (1.26\%), $\mathrm{CO}_{2}(5 \%), \mathrm{H}_{2}(5 \%)$, and $\mathrm{H}_{2} \mathrm{O}(5 \%)$ diluted in argon. Results are displayed in Figure 8 for the reactants and the $C_{2}$ products, including ethane, which is produced in very low amounts (maximum $2 \mathrm{ppm}$ ) at moderate temperatures. The global behavior looks close to that obtained with the first mixture involving $\mathrm{CO}$, but the addition of $\mathrm{CO}_{2}$ promotes the reactivity, as observed during neat methane pyrolysis. The profiles of products are also modified. The model simulates well the results. Methane and carbon dioxide consumption are very well represented as functions of the temperature, as CO and $\mathrm{H}_{2}$ behavior. As in the case of the $\mathrm{CO}$ blend, ethylene and acetylene peak values are at the right temperature but are somewhat underestimated. Unlike in steam reforming in which $\mathrm{C}_{2}$ were a little overestimated by the model (Figure 1), the high fraction of hydrogen in the mixture disadvantage the formation of $\mathrm{C}_{2}$ by the combination of methyl radicals and 
the subsequent dehydrogenation. The model may overvalue this effect at the highest temperatures. Ethane profile is very well reproduced.

Methane consumption starts at lower temperature than in the case of the CO blend. An experimental methane conversion around $6 \%$ is achieved at $1423 \mathrm{~K}$, whereas the COcontaining mixture does not react. At $1573 \mathrm{~K}$, the conversion reaches $60 \%$ in the $\mathrm{CO}_{2}$ blend and $45 \%$ in the $\mathrm{CO}$ blend, respectively. The amount of the final products from reforming are also modified. In the CO-containing mixture, methane reforming leads to the formation of hydrogen, $\mathrm{CO}$ and $\mathrm{C}_{2}$, which are converted thereafter to $\mathrm{CO}$ and $\mathrm{H}_{2}$. Meanwhile, a small part of $\mathrm{CO}$ is oxidized into $\mathrm{CO}_{2}$. When $\mathrm{CO}$ is replaced by $\mathrm{CO}_{2}$ in the blend, this compound acts as an oxidizer, as discussed above in the case of pure methane pyrolysis. The water gas shift reaction, induced by the reaction of an $\mathrm{H}$-atom with $\mathrm{CO}_{2}$ yielding $\mathrm{CO}$ and an $\mathrm{OH}$ radical, leads to the oxidation of $\mathrm{H}_{2}$ into water. In Figure 8 , it appears that half of the $\mathrm{CO}_{2}$ content is reduced to $\mathrm{CO}$ at high temperature, while the profile of $\mathrm{H}_{2}$ exhibits a V-shape as a function of temperature. At moderate methane conversion, up to $1573 \mathrm{~K}$, hydrogen consumption exceeds the production from the hydrocarbon reforming. When the temperature increases, the hydrogen formation from methane balances the oxidation of $\mathrm{H}_{2}$ by $\mathrm{CO}_{2}$. The promoting effect of $\mathrm{CO}_{2}$ on the reforming reaction is also noticeable on the profiles of ethylene and acetylene. The amounts of unsaturated $\mathrm{C}_{2}$ are almost the same for both mixture up to $1523 \mathrm{~K}$, but differentiate at higher temperatures. In the case of the $\mathrm{CO}_{2}$ blend, peak values are reached at a lower temperature and with a lower maximum amount than in the case of the CO blend (2500 ppm of acetylene instead of 3600 ppm, 144 ppm of ethylene instead of $326 \mathrm{ppm})$. The higher concentration of hydroxyl radical promoted by the reaction of carbon dioxide permits a larger consumption of methyl radical by termination with $\mathrm{OH}$ and 
furthermore favors ethylene and acetylene consumption, which produces oxygenated species.
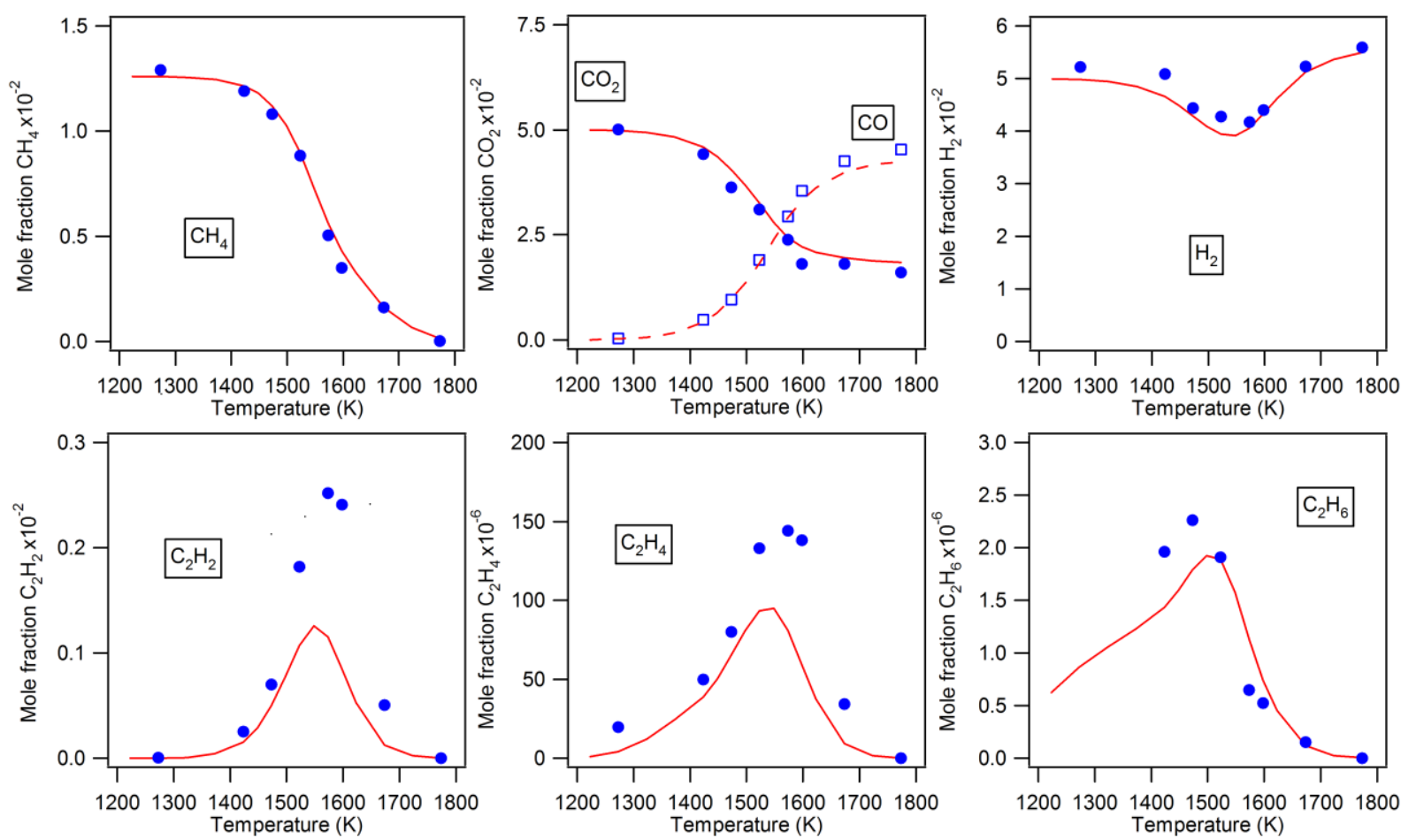

Figure 8: Profiles of species during the reaction of a mixture methane (1.26\%), $\mathrm{CO}_{2}$ $(5 \%), \mathrm{H}_{2}(5 \%), \mathrm{H}_{2} \mathrm{O}(5 \%)$ as a function of temperature. Residence time is $0.68 \mathrm{~s}$. Points represent experimental results and line simulations.

The model shows that in all the conditions studied, the hydrocarbon reforming does not go mainly through direct reactions of molecules or hydrocarbon radicals with water, but by the addition of $\mathrm{OH}$ radical on unsaturated bonds, which produced oxygenated species leading ultimately to $\mathrm{CO}$ and $\mathrm{CO}_{2}$. Figure 9 presents the main reaction pathways of the thermal reaction of methane in the presence of water, in the conditions of figure 8 at $1573 \mathrm{~K}$. The analysis is made in the middle of the plug flow reactor, corresponding to a simulated methane conversion of around $24 \%$. It appears that, even if a part of methyl radicals reacts with water or $\mathrm{OH}$ radicals yielding methanol or $\mathrm{CH}_{2} \mathrm{OH}$, respectively, these reaction routes account for only $8 \%$ of the net flux of consumption of methyl radicals. The 
main reaction channel is the combination with another methyl radical yielding $\mathrm{C}_{2} \mathrm{H}_{6}$, $\mathrm{C}_{2} \mathrm{H}_{5}+\mathrm{H}$ or $\mathrm{C}_{2} \mathrm{H}_{4}+\mathrm{H}_{2}$. The formation of $\mathrm{C}_{2}$ accounts for $81 \%$ of methyl consumption. Remaining reactions consuming methyl radicals are $\mathrm{H}$-atom abstractions on products, such as formaldehyde, which produces methane, and additions to unsaturated molecules, which yield heavier soot precursors. Ethane and ethylene dehydrogenate quickly by pericyclic $\mathrm{H}_{2}$ eliminations (concerted molecular elimination through a cyclic transition state) or by successive $\mathrm{H}$-atom abstractions and radical decompositions. Large amounts of acetylene, which is more stable, are eventually produced. This latter can react by addition of an $\mathrm{OH}$ radical. This reaction is the main channel in these conditions and represents $61 \%$ of acetylene consumption. Formation of propyne, a precursor of aromatic rings, accounts for $23 \%$ of acetylene consumption, while $\mathrm{H}$-atom abstractions yielding $\mathrm{C}_{2} \mathrm{H}$ radicals represents $10 \%$ of the flux. Remaining reactions include $\mathrm{C}_{4}$ formation. Note that in these conditions, very reactive $\mathrm{C}_{2} \mathrm{H}$ radicals react mainly with $\mathrm{CO}_{2}$ to produce $\mathrm{CO}$ and $\mathrm{HCCO}$ radicals.

Even in presence of a large amount of water, methane reacts mostly as in pyrolysis. The presence of $\mathrm{H}_{2}$ in the blend inhibits slightly the successive dehydrogenations of the $\mathrm{C}_{2}$, but does not really change the main reaction route. Note that in this mixture, the inhibiting effect of $\mathrm{H}_{2}$ on methane conversion is due to its reactions with methyl radicals, as in pyrolysis, but also to the competition between reaction channels of $\mathrm{OH}$ radicals with methane and $\mathrm{H}_{2}\left(\mathrm{H}_{2}+\mathrm{OH}=\mathrm{H}_{2} \mathrm{O}+\mathrm{H}\right)$. A major consequence of the pyrolysis-like reaction of methane is that the reforming is enabled by the formation of unsaturated hydrocarbons, which are in the same time soot precursors. Oxygenated compounds are produced by the addition of $\mathrm{OH}$ on ethylene, yielding formaldehyde and a methyl radical, and predominantly on acetylene, yielding ketene and an $\mathrm{H}$-atom. These oxygenates, much more reactive than methane at this high temperature, react quickly to produce $\mathrm{CO}$ in few 
steps. Meanwhile, acetylene reacts with methyl radicals to produce propyne, which leads to propargyl radicals, and then to aromatic rings. There is then a competition between the fast pyrolysis process, which leads ultimately to soot and solid carbon and the somewhat slow reforming producing oxygenated species, which decompose into CO. The high temperature necessary to methane reforming by water in the reducing blend issued from gasification makes unavoidable the formation of heavy unsaturated compounds, soot and carbon deposits.

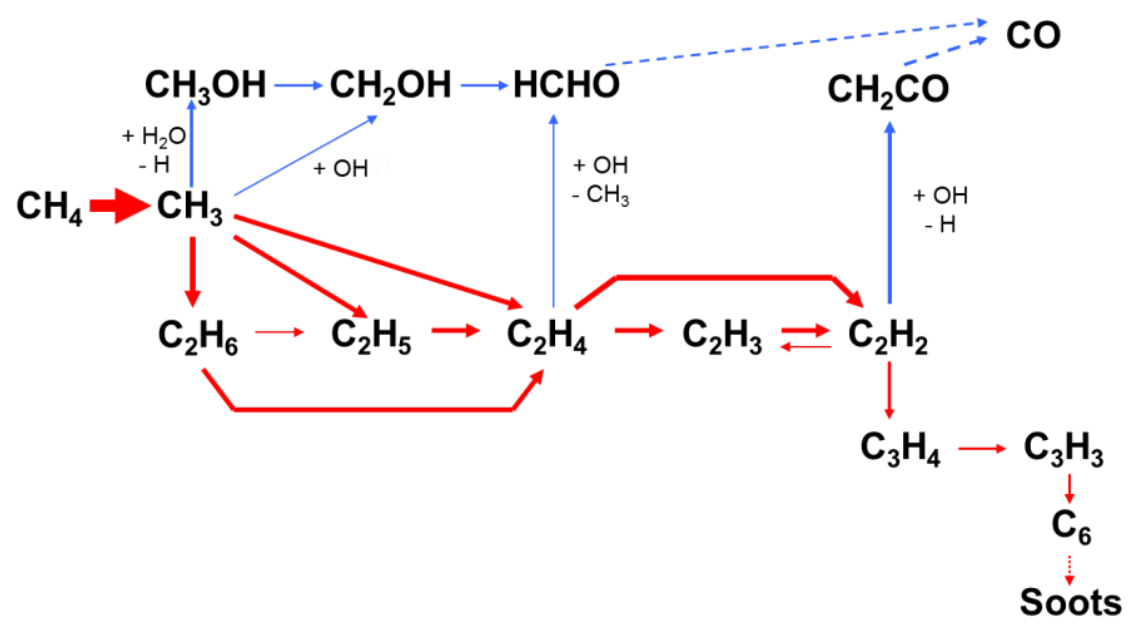

Figure 9: Reaction flux in steam reforming of methane in a mixture $\mathrm{CH}_{4} / \mathrm{CO}_{2} / \mathrm{H}_{2} / \mathrm{H}_{2} \mathrm{O}$ at $1573 \mathrm{~K}$ in condition of Figure 8 . Analysis performed in the middle of the flow reactor, corresponding to a simulated conversion of $24 \%$. Arrow thickness is proportional to the net flux. Red arrows represent the pyrolysis channel, blue arrows the reforming one.

\section{Conclusion}

The pyrolysis and the steam reforming of methane has been studied at high temperature, as well as the behavior of complex mixtures representative of that produced by the gasification of the lignocellulosic biomass. It appears that near atmospheric pressure and for a residence time of $0.68 \mathrm{~s}$, methane starts reacting at temperature below $1400 \mathrm{~K}$ and that it is necessary to heat up to more than $1700 \mathrm{~K}$ to achieve a complete reforming. The presence of carbon monoxide was found to have no kinetic effect, 
whereas carbon dioxide slightly promote the reaction by acting as an oxidizer. While hydrogen has a strong inhibiting effect, water does not influence dramatically the global rate of reaction but the product distribution. Since reaction of methyl radical with water or $\mathrm{OH}$ radicals are slow in comparison with the pyrolysis reactions, an important point is that the reforming process implies the formation of unsaturated compounds, on which $\mathrm{OH}$ radicals can add, but which are also soot precursors. A limitation of a temperature reforming process could then limit the energetic cost and the soot and carbon deposit formation.

\section{Acknowledgement}

This work was granted by the "Agence Nationale pour la Recherche" through the CINE-HT project. 


\section{References}

[1] Demirbas A. Potential applications of renewable energy sources, biomass combustion problems in boiler power systems and combustion related environmental issues. Prog Energy Combust Sci 2005;31:171-92. doi:10.1016/j.pecs.2005.02.002.

[2] Klose W, Wölki M. On the intrinsic reaction rate of biomass char gasification with carbon dioxide and steam. Fuel 2005;84:885-92.

[3] Di Blasi C. Modeling chemical and physical processes of wood and biomass pyrolysis. Prog Energy Combust Sci 2008;34:47-90. doi:doi: 10.1016/j.pecs.2006.12.001.

[4] Gómez-Barea A, Leckner B. Modeling of biomass gasification in fluidized bed. Prog Energy Combust Sci 2010;36:444-509. doi:10.1016/j.pecs.2009.12.002.

[5] Yoon HC, Cooper T, Steinfeld A. Non-catalytic autothermal gasification of woody biomass. Int J Hydrog Energy 2011;36:7852-60. doi:10.1016/j.ijhydene.2011.01.138.

[6] Evans RJ, Milne TA. Molecular characterization of the pyrolysis of biomass. Energy Fuels 1987;1:123-37. doi:doi: 10.1021/ef00002a001.

[7] Tijmensen MJA, Faaij APC, Hamelinck CN, van Hardeveld MRM. Exploration of the possibilities for production of Fischer Tropsch liquids and power via biomass gasification. Biomass Bioenergy 2002;23:129-52. doi:doi: 10.1016/S09619534(02)00037-5.

[8] Shen Y, Yoshikawa K. Recent progresses in catalytic tar elimination during biomass gasification or pyrolysis-A review. Renew Sustain Energy Rev 2013;21:371-92. doi:10.1016/j.rser.2012.12.062.

[9] Palumbo AW, Jorgensen EL, Sorli JC, Weimer AW. Co-processing methane in high temperature steam gasification of biomass. Bioresour Technol 2013;128:5539. doi:10.1016/j.biortech.2012.10.033.

[10] Palumbo AW, Sorli JC, Weimer AW. High temperature thermochemical processing of biomass and methane for high conversion and selectivity to $\mathrm{H} 2$-enriched syngas. Appl Energy 2015;157:13-24. doi:10.1016/j.apenergy.2015.07.072.

[11] Anis S, Zainal ZA. Tar reduction in biomass producer gas via mechanical, catalytic and thermal methods: A review. Renew Sustain Energy Rev 2011;15:2355-77. doi:10.1016/j.rser.2011.02.018.

[12] Pregger T, Graf D, Krewitt W, Sattler C, Roeb M, Moeller S. Prospects of solar thermal hydrogen production processes. Int J Hydrog Energy 2009;34:4256-67. doi:10.1016/j.ijhydene.2009.03.025.

[13] Trommer D, Noembrini F, Fasciana M, Rodriguez D, Morales A, Romero M, et al. Hydrogen production by steam-gasification of petroleum coke using concentrated solar power-l. Thermodynamic and kinetic analyses. Int J Hydrog Energy 2005;30:605-18. doi:10.1016/j.ijhydene.2004.06.002.

[14] Z'Graggen A, Steinfeld A. Hydrogen production by steam-gasification of carbonaceous materials using concentrated solar energy - V. Reactor modeling, optimization, and scale-up. Int J Hydrog Energy 2008;33:5484-92. doi:10.1016/j.ijhydene.2008.07.047.

[15] Karim GA, Wierzba I. The production of hydrogen through the uncatalyzed partial oxidation of methane in an internal combustion engine. Int J Hydrog Energy 2008;33:2105-10. doi:10.1016/j.ijhydene.2008.01.051. 
[16] Kim S, Dean AM, Bae J. Coupled transport and kinetics in the mixing region for hydrocarbon autothermal reforming applications. Int J Hydrog Energy 2013;38:16140-51. doi:10.1016/j.ijhydene.2013.09.119.

[17] Xie D, Zhao J, Wang Z, Zhang Y. Syngas production from oxidative methane reforming and $\mathrm{CO}$ cleaning with water gas shift reaction. Int J Hydrog Energy 2013;38:10826-32. doi:10.1016/j.ijhydene.2013.01.012.

[18] Guiberti TF, Garnier C, Scouflaire P, Caudal J, Labegorre B, Schuller T, et al. Experimental and numerical analysis of non-catalytic partial oxidation and steam reforming of $\mathrm{CH} 4 / \mathrm{O} 2 / \mathrm{N} 2 / \mathrm{H} 2 \mathrm{O}$ mixtures including the impact of radiative heat losses. Int J Hydrog Energy 2016;41:8616-26. doi:10.1016/j.ijhydene.2016.03.009.

[19] Stendardo S, Foscolo PU, Nobili M, Scaccia S. High quality syngas production via steam-oxygen blown bubbling fluidised bed gasifier. Energy 2016;103:697-708. doi:10.1016/j.energy.2016.03.011.

[20] Kim S, Bae J. Numerical analysis of a $20-\mathrm{kWe}$ biogas steam reformer in PEMFC applications. Int J Hydrog Energy 2014;39:19485-93. doi:10.1016/j.ijhydene.2014.09.137.

[21] Jönsson $O$. Thermal cracking of tars and hydrocarbons by addition of steam and oxygen in the cracking zone. Fundam. Thermochem. Biomass Convers. Elsevier Applied Science, London: R. Overend, T. Milne and L. Mudge editors; 1985, p. 733-46.

[22] Tijmensen MJA. The production of Fischer Tropsch liquids and power through biomass gasification, Thesis of Utrecht University, 2000. Utrecht University, 2000.

[23] Valin S, Cances J, Castelli P, Thiery S, Dufour A, Boissonnet G, et al. Upgrading biomass pyrolysis gas by conversion of methane at high temperature: Experiments and modelling. Fuel 2009;88:834-42. doi:10.1016/j.fuel.2008.11.033.

[24] Dufour A, Valin S, Castelli P, Thiery S, Boissonnet G, Zoulalian A, et al. Mechanisms and Kinetics of Methane Thermal Conversion in a Syngas. Ind Eng Chem Res 2009;48:6564-72. doi:10.1021/ie900343b.

[25] Brage C, Yu Q, Chen G, Sjöström K. Tar evolution profiles obtained from gasification of biomass and coal. Biomass Bioenergy 2000;18:87-91. doi:10.1016/S0961-9534(99)00069-0.

[26] Jess A. Mechanisms and kinetics of thermal reactions of aromatic hydrocarbons from pyrolysis of solid fuels. Fuel 1996;75:1441-8. doi:10.1016/00162361(96)00136-6.

[27] Olsvik O, Billaud F. Modelling of the decomposition of methane at $1273 \mathrm{~K}$ in a plug flow reactor at low conversion. J Anal Appl Pyrolysis 1993;25:395-405. doi:10.1016/0165-2370(93)80058-8.

[28] Ranzi E, Sogaro A, Gaffuri P, Pennati G, Faravelli T. A Wide Range Modeling Study of Methane Oxidation. Combust Sci Technol 1994;96:279-325. doi:10.1080/00102209408935359.

[29] Tan Y, Dagaut P, Cathonnet M, Boettner J-C. Oxidation and Ignition of MethanePropane and Methane-Ethane-Propane Mixtures: Experiments and Modeling. Combust Sci Technol 1994;103:133-51. doi:10.1080/00102209408907691.

[30] Marinov NM, Pitz WJ, Westbrook CK, Lutz AE, Vincitore AM, Senkan SM. Chemical kinetic modeling of a methane opposed-flow diffusion flame and comparison to experiments. Symp Int Combust 1998;27:605-13. doi:10.1016/S0082-0784(98)80452-9.

[31] Petersen EL, Davidson DF, Hanson RK. Kinetics modeling of shock-induced ignition in low-dilution $\mathrm{CH} 4 / \mathrm{O} 2$ mixtures at high pressures and intermediate 
temperatures. Combust Flame 1999;117:272-90. doi:10.1016/S00102180(98)00111-4.

[32] Smith GP, Golden D, Frenklach M, Moriarty N, Eiteneer B, Goldenberg M, et al. GRI-Mech 3.0. Http://www.me.berkeley.edu/gri_mech/n.d. http://www.me.berkeley.edu/gri_mech/.

[33] Hughes KJ, Turányi T, Clague AR, Pilling MJ. Development and testing of a comprehensive chemical mechanism for the oxidation of methane. Int $\mathrm{J}$ Chem Kinet 2001;33:513-38. doi:10.1002/kin.1048.

[34] Zhu J, Zhang D, King KD. Reforming of $\mathrm{CH} 4$ by partial oxidation: thermodynamic and kinetic analyses. Fuel 2001;80:899-905. doi:10.1016/S0016-2361(00)00165-4.

[35] de Ferrières S, El Bakali A, Lefort B, Montero M, Pauwels JF. Experimental and numerical investigation of low-pressure laminar premixed synthetic natural gas/O2/N2 and natural gas/H2/O2/N2 flames. Combust Flame 2008;154:601-23.

[36] Konnov AA, Barnes FJ, Bromly JH, Zhu JN, Zhang D. The pseudo-catalytic promotion of nitric oxide oxidation by ethane at low temperatures. Combust Flame 2005;141:191-9. doi:10.1016/j.combustflame.2005.01.003.

[37] Metcalfe WK, Burke SM, Ahmed SS, Curran HJ. A Hierarchical and Comparative Kinetic Modeling Study of C1 - C2 Hydrocarbon and Oxygenated Fuels. Int J Chem Kinet 2013;45:638-675. doi:10.1002/kin.20802.

[38] Fournet R, Bauge JC, Battin-Leclerc F. Experimental and modeling of oxidation of acetylene, propyne, allene and 1,3-butadiene. Int J Chem Kinet 1999;31:361-79.

[39] Gueniche HA, Biet J, Glaude PA, Fournet R, Battin-Leclerc F. A comparative study of the formation of aromatics in rich methane flames doped by unsaturated compounds. Fuel 2009;88:1388-1393.

[40] Burcat A, Goos E, Ruscic B. Third Millennium Ideal Gas and Condensed Phase Thermochemical Database for Combustion 2013. http://garfield.chem.elte.hu/Burcat/burcat.html.

[41] Baulch DL, Bowman CT, Cobos CJ, Cox RA, Just T, Kerr JA, et al. Evaluated Kinetic Data for Combustion Modeling: Supplement II. J Phys Chem Ref Data 2005;34:757-1397. doi:10.1063/1.1748524.

[42] Jasper AW, Klippenstein SJ, Harding LB, Ruscic B. Kinetics of the Reaction of Methyl Radical with Hydroxyl Radical and Methanol Decomposition†. J Phys Chem A 2007;111:3932-50. doi:10.1021/jp067585p.

[43] Dean AM, Westmoreland PR. Bimolecular QRRK analysis of methyl radical reactions. Int J Chem Kinet 1987;19:207-28. doi:10.1002/kin.550190305.

[44] Tsang W, Hampson RF. Chemical Kinetic Data Base for Combustion Chemistry. Part I. Methane and Related Compounds. J Phys Chem Ref Data 1986;15:1087279. doi:10.1063/1.555759.

[45] Woods IT, Haynes BS. C1/C2 chemistry in fuel-rich post-flame gases: Detailed kinetic modelling. Symp Int Combust 1994;25:909-17. doi:10.1016/S00820784(06)80726-5.

[46] Glaude PA, Pitz WJ, Thomson MJ. Chemical kinetic modeling of dimethyl carbonate in an opposed-flow diffusion flame. Proc Combust Inst 2005;30:11111118.

[47] Buda F, Bounaceur R, Warth V, Glaude PA, Fournet R, Battin-Leclerc F. Progress toward a unified detailed kinetic model for the autoignition of alkanes from $\mathrm{C} 4$ to C10 between 600 and 1200 K. Combust Flame 2005;142:170-186.

[48] Kee RJ, Rupley FM, Miller JA. CHEMKIN-II: A FORTRAN Chemical Kinetics Package for the Analysis of Gas-Phase Chemical Kinetics 1993. 
[49] Ziegler-Devin I, Fournet R, Marquaire P-M. Pyrolysis of propane for CVI of pyrocarbon: Part III: Experimental and modeling study of the formation of pyrocarbon. J Anal Appl Pyrolysis 2007;79:268-77. doi:10.1016/j.jaap.2006.10.004. 